\title{
Life reform, educational reform and reform pedagogy from the turn of the century up until 1945 in Hungary
}

\author{
András Németh \\ email: nemeth.andras@ppk.elte.hu \\ Eötvös Loránd University. Hungary / János Selye University Komárno. Slovakia \\ Béla Pukánszky \\ email: bela@pukanszky.hu \\ University Szeged. Hungary / János Selye University Komárno. Slovakia
}

\begin{abstract}
Since the end of the 19th century, the modernisation processes of urbanisation and industrialisation taking place in Europe and the transatlantic regions have changed not only the natural environment but also social and geographical relations. The emergence of modern states changed the traditional societies, lifestyles and private lives of individuals and social groups. It is also characteristic of this period that social reform movements appeared in large numbers - as a «counterweight» to unprecedented, rapid and profound changes. Some of these movements sought to achieve the necessary changes with the help of individual self-reform. Life reform in the narrower sense refers to this type of reform movement. New historical pedagogical research shows that in the major school concepts of reform pedagogy a relatively close connection with life reform is discernible. Reform pedagogy is linked to life reform - and vice versa. Numerous sociotopes of life reform had their own schools, because how better to contribute than through education to the ideal reproduction and continuity of one's own group. Our work ties in with this pedagogical research direction. The background to the first part of the study is a long-term project aimed at promoting contacts in life reform and reform pedagogy in the Austro-Hungarian monarchy and later in Hungary. In the second part we analyse the process up to 1945, in which the ideas of life reform and the elements of reform pedagogy were institutionalised and integrated into the official pedagogical guidelines of the Hungarian universities.
\end{abstract}

Keywords: Life reform; reform pedagogy; Austro-Hungarian monarchy; emantipation.

Received: 13/01/2019

Accepted: 11/05/2019

\section{Introduction}

The new, mainly German, research shows that in the large school concepts of reform pedagogy (Landerziehungsheime, Waldorf- and Jenaplanschool, etc.) 
a relatively close connection to life reform can be discerned. Reform pedagogy is linked to life reform - and vice versa. Numerous life reform sociotopes had their own schools, for how better than through education could one contribute to the ideal reproduction and continuity of one's own group. Life reform ideas influenced numerous leading personalities, who often became spokespeople for various social and educational reform movements. (Oelkers, 1989; Bilstein, 2000; Scholz, 2002; Mietzner, 2002; Skiera, 2003, 2006, 2017; Baader, 2005).

Our paper ties in with this pedagogy history research. The background of which is a long-standing international project supported by the Hungarian National Research Fund ${ }^{1}$. In the focus are the establishment tendencies of the life reform and reform pedagogy in the time of the Austrian-Hungarian monarchy and its new developments as well as educational motives in Hungary after the disintegration of the monarchy. In the second part of this article we analyze the process up until 1945 , in which the ideas of life reform and the elements of reform pedagogy became institutionalized and integrated into the official pedagogical directives of Hungarian universities. In addition to the broad international specialist literature, it is based on hermeneutical analyses of contemporary archive documents, specialist publications, journals and contemporary books.

The following questions are of interest: What are the difficulties of pedagogically motivated social reforms in modernity? Where do the starting points in the life reform for totalitarian ideologies, for philosophy and religion (new religions)? Which important persons of the reform ideas were important in Central Europe and Hungary? What are the country-specific characteristics of life reform and the associated reform pedagogical directions in the region? What similarities are noteworthy between Central European and Hungarian efforts in the field of life reform and reform pedagogy? What are the educational policy implications of the reform pedagogical currents in Hungary? What role did they play in the development of Hungarian pedagogy and teacher training?

\section{Life reform and its connection to reform pedagogy}

Since the seventies and eighties of the 19th century, the urbanisation and industrialisation processes of modernisation unfolding in Europe and in the transatlantic regions have changed not only the natural environment, but also social and geographic relations. The emergence of modern states changed traditional societies, the lifestyle and private life of individuals and social groups. Moreover, the traditional order of how people experienced their partnerships, how they spent their free time, ate or dressed changed as well at an unprecedented rate.

It is also characteristic of this period that social reform movements appeared in large numbers - as a «counterweight» to the unprecedented, rapid and profound changes, they sought a remedy for the challenges of the evolving modern world. Some of the developing social reform movements were striving to change the state or society by political means, by seizing political power. The other main trend tried to

${ }^{1}$ Research Project (2015-2019) No. K111833 of the Hungarian Research Fund (OTKA) entitled Reform Pedagogy and Life Reform - Trends of Reception and Progress of Institutionalization. 
achieve the necessary changes with the help of the individual, with the fundamental transformation of his or her mentality and world view about the reform of human life. Life reform in the narrower sense refers to this type of reform movement. Their common characteristic was the effort to achieve existential changes in the interest of the future of society with the ideas of «return to nature» and «healthy lifestyle», with the reform of the individuals way of life, their habits of nutrition, their living environment, and the preservation of their health. With the term «life reform movement» we primarily refer to the complex context of the colourful totality of the various reform movements (garden city, soil reform movement, anti-alcoholic movement, vegetarian movement, naturopathy movement, physical culture movement), which have coined the phrase criticising the civilization: «flight from the city» - and thus promoted a new relationship between people, between men and nature, men and work, and with God (Krabbe, 2001, p. 25).

But these movements in their entirety and in light of their social impact meant far more. Wolbert, summarizing the significance of these movements, states the following:

Life reform is the concerted innovative epoch phenomenon around 1900 par excellence, and in it topics and problems were addressed which have not lost their explosive force even nowadays. (...) The reform of life is presented as the driving current in which those ideas, orientations and motives have emerged; that, on the one hand, have become manifest in the practical orientation towards existence as the modernization of everyday life, but on the other hand, also appeared equally in the spiritual and creative expressions of the time (Wolbert, 2001, p. 20).

The movement was thus a profound, colourful, cultural and social current between 1890 and 1914, which also played a central role in contemporary literature and visual arts. It can best be traced back to the feeling of rootlessness and homelessness that fundamentally determined the view of life of the fin de siécle.

According to Skiera $(2003,2006)$, all these moments of uncertainty form a fertile ground for a multitude of quasi-religious worldviews and secular doctrines of salvation that feed on numerous motifs of mythological, spiritual, political and pseudoscientific origin. Reform pedagogy is now closely linked to these movements through the common critical background of civilization and the vision of salvation. Reform pedagogy could only unfold its effect through this impulse directed towards the reform of life as a whole. And, as we will see in the future, many moments of life reform are reflected in reform pedagogical concepts. Life reform thus prepared and then supported reform pedagogy in many ways. This is still true today - let us think of the upswing of the anti-authoritarian alternative school movement since the early 1970 s in its connection with the ecological movement of the Greens within and outside the parliaments. Reform pedagogy itself can also be seen as a movement for life reform, because in almost all of its branches the motive of salvation can be found. Reform pedagogy was in its context of origin at the turn of the 20th century and is in its weakened form until today's rescue pedagogy. 
Skiera has some historical examples of this: Peter Petersen, for example, the founder of Jenaplan pedagogy and the Jenaplan school, envisions the new education embedded in the new society, which will be «inspired by community». Similarly, Maria Montessori speaks of the great task of education. «The plan of an education that wants to bring salvation must be based on the laws that guide human development. (...) To unite in harmony the mind and conscience of all men ... this is what we intend through Cosmic Education» (see: Skiera, 2003, p. $213 \mathrm{ff}$ ) The «World Movement» also has its World Saviour. It is called «child» and is the epitome of a better world in the future or even a world that will heal as a whole. This quasi-religious thought is repeated in the discourses of reform pedagogy. According to Montessori, the child is assigned to the «new Messiah» and the teacher in serving devotion is assigned to the development of himself and the future «new» human being decided in the child and they pursue a «New Age» (of peace, harmony and general happiness). The talk of the creative power or the "genius of the child» was frequent especially in the art education movement. This thought can be found especially in Ellen Key's work, in Maria Montessori's work, in Pawel Blonskij's work, in traces and remnants, but also in almost all other educational concepts of reform, which have a far higher ambition, namely the salvation of humanity (see: Skiera, 2006, pp. 29-30). In the spirit of this analysis, in the following we will see the establishment of life reform in the AustroHungarian Monarchy and its links with the educational reforms of the turn of the century.

\section{Life Reform in the Austro-Hungarian Monarchy}

As the processes of modernisation accelerated in the last third of the nineteenth century, they radically transformed the natural and social environment of the people of the day. The Austro-Hungarian Compromise (1867) and the creation of the German Empire (1871) not only brought about political stability and wide-ranging social and economic prosperity in the Central European region, but also reinforced the negative effects of industrialisation and urbanisation. Among these were the sudden, unchecked growth of metropolises, an increase in social conflicts and economic inequalities, the break-up of traditional communities, and the atomisation of people in the cities. Changes took place in the way people worked, their housing, their social relationships, leisure time, diet, clothing, and traditional community customs and religious practices. A common complaint against modernisation voiced by contemporary cultural critics was that the dramatic economic developments and subsequent profound social shifts had not been accompanied by substantial reforms in worldview, art or aesthetics. In response, artists with a desire to make change happen set about creating a new culture that would represent a «unity of artistic styles expressing every aspect of people's lives» (Németh \& Pukánszky, 2019).

The life reform (Lebensreform) movements that emerged in the late 19th century saw the transformation of everyday lifestyles and farming conditions as a means of overcoming the crises of the age. They expected the improvement of society to come from individual and collective actions performed on a day-to-day basis, leading to the creation of the harmonious world of the «new person», free of physical and mental diseases. The «Salvation theories» articulated by the movement follow 
the paradise - fall - redemption scheme, where redemption is found in a back-tonature lifestyle that eliminates and cures the maladies of civilisation. According to the teachings of its «prophets», paradise on earth will be open to those who follow the three basic principles of healthy living: a vegetarian diet, natural medicine and adherence to the principles and practice of «body culture». The movements founded on individual self-reform were also associated with numerous complementary socialpolitical, artistic and religious reform movements. Soon there were all kinds of new groups, varying in size and sometimes impenetrably interconnected, all of which wanted to reform people's way of living in different ways, and which sang new songs - about topics ranging from education and dress, dance, sport and diet, physical culture and natural healing, to female emancipation, youth, environment and nature conservation, patriotic awareness, applied arts groups, garden city movements and agricultural cooperatives - that combined into the diverse melody of the modern individual and communal worldview. (Németh, 2020)

Cafés and bourgeois salons played an outstanding role in the social life of the Monarchy's capital cities. These informal places offered an excellent opportunity to discuss new intellectual and artistic trends as well as scientific results and they contributed to the dissemination of fashionable ideas, movements and reform endeavours of the period. New ideas surfaced also in the blooming cafés in Wien and Budapest, important public fora of the age. The movement's meeting place in Wien was Café Griensteidl, an art café at Michaelerplatz, while the regular berth of Hungarian Gnostics and theosophists used to be Akadémiai Kávéház (Academy Café) in Budapest where also Henrik Schmitt Jenő, a well-known gnostic proselytizer of the time, often made an appearance. (Németh, 2017, pp. 78-79).

The teachings of modern esoterica are based on «ancient knowledge» and the occult belief systems of old (gnosticism, Kabbalah, alchemy, astrology), the traditions of Ancient Egypt, Ancient Europe (Celtic, Germanic, Mediaeval Cathar, Templar, Freemason, Rose Cross), and various Eastern religions (Hindu, Buddhist, Tibetan). Theosophy is a relatively recent occult movement that was created as a counter-response to the materialism and positivism of 19th century natural science. To distinguish it from earlier, similar occult doctrines, the movement is also referred to as Anglo-Indian Theosophy (Peters, 2005, pp. 16-43). The Hungarian Theosophy Society of Budapest was formed in 1906. The popular public talks given at the Academy of Music and other prestigious venues, the two Theosophy congresses held in Budapest, and visits by pioneers of the movement - including Annie Besant, Rudolf Steiner, Charles Webster Leadbeather, George Sidney Arundale and Jiddu Krishnamurti - also attracted many well-known public figures to the discipline. Anthroposophy, founded by Rudolf Steiner (1861-1925), is an esoteric, spiritual belief system built on evolutionary foundations, and a lifestyle and path to life reform in the narrower sense, as well as one of the trends that helped to define other movements that are based on these principles. Anthroposophy combines the various endeavours of the life reform movement (diet, clothing, agriculture, education, healing, and indeed - together with the reforming of society as a whole - the establishment of new forms of religion), but shapes them into a coherent, closed and unique system in which the various motifs gain new meaning. Steiner's holistic world view is built on 
the principles of Theosophy as articulated by Helena Blavatsky, but also distances itself from many aspects of them. (Irtl\& Komár, 2017, p.121; Németh, 2020).

The list of people who showed an interest, or even became active members, includes the electrical engineer Károly Zipernowszky (1853-1942), the artist Róbert Nádler (1858-1938), composer and folk song collector Zoltán Kodály (1882-1967), poets and writers such as Sándor Weöres (1913-1989), Frigyes Karinthy (18871938), Emma Vadnay, János Kodolányi (1899-1969), Nándor Várkonyi (1896-1975) and Lőrinc Szabó (1900-1957), and the painter Simon Hollósy (1857-1918). During the Second World War, the society was first disbanded «on paper», and then in 1950 it really did cease to exist, when its assets were seized and a substantial part of its valuable library was pulped (Irtl\& Komár 2017, p.122).

The central idea of the Life Reform Movement is to return to nature and to a natural way of life. Health resorts were created to serve this purpose. At these places people were given help to recover from their illnesses in a natural way. These plases brought about the changes in the people's way of life necessary for self-healing by adopting it to the rhythm of nature. Natural cures were based on patients' natural will to recover and the healing power of nature. Practitioners of natural medicine professed that people can be cured by natural procedures with the help of the four ancient elements of light, water, air and earth. Several spas, sanatoriums and medicinal centres were opened throughout Europe in this spirit, where health, the unification of body and soul was helped by traditional medicine, hot, hot and cold, and medicinal baths, herbal treatments, light-, air- and mineral baths and a natural diet. The sanatoriums of Vincenz Priessnitz (1799-1851) and Sebastian Kneipp (1821-1897), Arnold Rikli (1923-1906), and Adolf Just (1859-1936) provided the most important models for health resorts, which mushroomed in Europe, where, in addition to classical medical techniques, therapies integrated healthy diets, natural movement and - a little later - artistic group activity, too, which had an impact on the body, the soul and the intellect at the same time and helped the development of a healthy and harmonious order of life. Kneipp's and Just's resorts became very popular in the countries of the Austrian-Hungarian Monarchy as well. Károly Siklósy's Institute of Medical Exercise and Water Therapy, which integrated Priessnitz's, Schrott's and Ling's approaches opened in 1853. In the 1870s there were about a hundred physicians who applied homeotherapy, and a Department of Homeopathy was set up at the Medical University of Pest, led first by Ferenc Hausmann (18121876) and then by Teodor Bakody (1825-1911). Bakody edited Hasonszenvi Lapok (Papers on Homeopathy) from 1861 and Homeopátia Szakközlönye (Homeopathy Review) from 1891. At the turn of the 19th and 20th century, several sanatoriums were founded (Farkas, 2008, pp.12-14; Németh, 2020).

Several considerations have motivated people to discard food of animal origin in the long history of vegetarianism. Many of them have been present at the same time though with different emphasis: moral ones, the protection of animals, self-healing, a healthy way of life and the wish to live long. As the followers of vegetarianism usually lived in a separate community, or separate communities incorporated vegetarianism in their way of life, they often embraced radical social, humanitarian or religious reform ideas, which challenged the way of life of the carnivorous main stream society. Vegetarianism started to be organized as a movement in 19th 
century England. The Hungarian Vegetarian Society was founded in 1883. Its first president was Vince Weixelgartner (1826-1915), painter, teacher and operator of the Promona reform restaurant. Henrik Ripszám (1864-1939), the owner of Thalysia, a vegetarian restaurant, advertised vegetarianism as a guarantee for long life. Béla Bicsérdy (1872-1951), the founder of the movement named after him and becoming very popular in Hungary and in Transylvania attributed his recovery from his illness, his long life, and his successes in sports to eating raw vegetable and fruit. His movement was joined by several well-known Hungarian artists, including Dezső Kosztolányi (1885-1936), Mihály Babits (1883-1941), Béla Bartók (1881-1945) and Zoltán Kodály (1882-1967). Vegetarianism became the common principle of life and the basis of the way of life of Life Reform movements and alternative endeavours such as some artists' colonies, producer communities and Esperantists, at the turn of the 19th and 20th century. The community of the artists' colony in Gödöllö made vegetarianism an integral part of its attitude and daily practice together with every other element of the reformed way of life (Németh, 2017, pp. 65-69).

The Central European model for rural farming communes was provided by the Obstbausiedlung Eden (fruit-growing settlement of Eden), established in 1893 in Berlin Oranienburg. Various types of similar communities were formed across Europe in their wake, with the most frequent ones including communities pursuing selfsufficient horticulture, a close-to-nature lifestyle on the edges of towns and a selfsufficient rural agricultural activity. Besides the slogans of the lifestyle reform's health cult, the ideological elements of the producer and consumer cooperatives and land reform movements were also present. The chapter of Hungarian vegetarian producer communes was opened by Béla Bicsérdy (1872-1951), who founded a short-lived community with his wife and followers on the small island of Ada Kaleh on the Lower Danube. These settlers took cold baths all year round, wore light and loose reform clothing, and were eager readers of books on sociology and the natural sciences as well as writings about biology, natural diets and Buddhism. The other farming commune in Hungary with a somewhat longer lifespan was the Bubán colony in Szentendre, which started its operation on the plot of land owned by painter Sándor Markó (1902-1993). By 1935 the community had 24 families and 90 members. Each family farmed 1 or 2 acres of land, on which they grew the plants needed for their diet. They even published a periodical, titled Life Reform, from 1932, in which they published articles about the subject (Nagy \& Németh, 2017, pp. 58-64).

The reform endeavours of the 19th century, most of all the idea of returning to nature, to a traditional way of life and fine craftsmanship, which was first formulated by John Ruskin (1819-1900), William Morris (1834-1896) and members of the Pre-Raphaelite Brotherhood, found followers among a number of other artists as well. Attracted by unspoilt countryside, many artists in France, England, the United States, Northern and Eastern Europe and in Hungary, too, moved out of the towns and set up colonies. The artists who chose to live in the country were hoping to find a simple and pure life. Due to the congeniality of their artistic and intellectual attitude and their similar habits, they developed a new communal way of life. In their works they often portrayed nature with symbolic and metaphysical connotations. Their houses were frequently designed by an architect who lived in the same commune, and they were furnished by pieces made by themselves. They used objects in 
their household, which were handcrafted in their own workshop. In Hungary, such creative communities were founded in Nagybánya [Baia Mare], Kecskemét, Szolnok and Gödöllö. The most comprehensive programme was implemented by the colony of Gödöllö. The artists and their families who gathered around the two leading figures, Aladár Körösfői-Kriesch (1863-1920) and Sándor Nagy (1869-1950), shared a common attitude, which was closely connected to Life Reform, and carried out their creative activity in the community. Artists' colonies endorsed developing close relationships between different national cultures. The members of the artists' colony thought that they had discovered the living tradition of the ideal world of the Middle Ages at Kalotaszeg. With their artwork closely related to folk art, their attitude influenced the national architecture of Károly Kós (1883-1977) and other architects, the extensive research work on folk art initiated by Dezső Malonyai (1866-1916), who published his five volume seminal work on The Art of the Hungarian People [A magyar nép művészete] in 1907, and the collection of folk songs by Zoltán Kodály (1882-1967) and Béla Bartók (1881-1945) (Németh, 2017, pp. 75-77).

\subsection{Women and life reform}

The wife of Oszkár Jászi, the versatile painter and poet Anna Lesznai (18851966), was also familiar with the circle. She was one of the few who did not join the communist movement. After the turn of the century, she wrote numerous wellknown fairy tales, which she illustrated herself. (The Days of the Baby Bean, Tales of the Strawberry Heart, Tales of the Furniture and the Boy, The Journey of the Little Butterfly on Leszna and in the Neighbouring Land of Fairies). With the help of the beautifully composed illustrations and the poetic fairy tale world connected with them, the reader, i.e. the child, grasps his environment like a miracle, step by step, the fairy tales open the eyes of the little readers to the mysticism of the environment in a simple way (Szabadi, 1978, pp. 89-95).

Artistic dance schools, appearing in the first decades of the century, were popular among Budapest's civil and aristocratic circles. These schools followed Duncan's free dance and Mensendieck's and Jaques-Dalcroze's rhythmic method. The renowned representative of the movement is the mathematician, philosopher Valéria Dienes (1879-1978), who was connected to the reform movements by her husband, Pál Dienes (1882-1952). Later she moved to Paris, where she was a student of Bergson. Later she became a follower and a translator of his works to Hungarian. In her recollection, Bergson's movement psychology (Bergson, 1896), the renowned dancer, Isadora Duncan and her brother, Raymond Duncan influenced her concept the most. In the early twenties, with her children she joined Raymond Duncan's lifereform community in Nice. (For the main areas of the work of Valéria Dienes see Fenyves 2016) After returning home she also taught her orchestration in her own school and in the reform school of Mrs. Domokos (Emma Löllbach). Mrs. Madzsar (Alice Jászi) ${ }^{2}$ has learned her method at Bessy Mensendieck's Institute in Norway and started her first gymnastic courses at the same time as Valéria Dienes did in 1912.

${ }^{2}$ Alice Jászi (1877-1935): hungarian dance pedagogue, movement artist, One of the founders of the hungarian physiotherapy. 
(For Alice Madzsar's life and work in details see Zaletnyik \& Repiszky, 2012) Inspired by Mensendieck she worked mainly on the development of women's health-care exercises. She also worked on exercises for pregnant women, a plan of workplace exercises that compensated for the workplace challenges and child rearing. She also had significant influence in introducing a new approach to physiotherapy. Later she dedicated two books to the healthy female exercise and the art that emerged from it. From the 1920s she participated in the theatrical experiments of Ödön Palasovszky ${ }^{3}$ with her followers. Pianist Olga Szentpál ${ }^{4}$ learned the method of the Swiss teacher, Emile Jaques-Dalcroze as a participant of the rhythmic movement course in Hellerau, and in 1919 she opened her rhythmic-exercise school. Thanks to her and Lili Kállai and their followers, Dalcroze's method has been widely accepted by the citizens of Budapest (Kékesi \& Schuller, 2003)

\subsection{Life reform and educational reform in the capital of Bárczy after 1906}

The life reform efforts and the pedagogical reform ideas came into contact with each other in the professional and emancipation movements of the elementary school teachers, who were an increasingly important professional force, as well as in the urban reforms of István Bárczy in Budapest. István Bárczy, the liberal mayor, headed the capital between 1906 and 1918. During this decade, the Bárczy era, the city developed into a cosmopolitan city. The majority of the «building mayor's» buildings, schools, public buildings, apartment buildings, still stand today. This period saw the expansion of the city administration, public transport, lighting and the municipal system. As part of the social and cultural policy programme, the construction of numerous small apartments and schools began. Significant steps were taken to expand adult education, and under the leadership of Ervin Szabó in the 1910s a modern network of libraries was established in Budapest. After 1909, the extensive construction of schools formed an important part of Bárczy's cultural-political programme, in the course of which 36 new schools were built and numerous school buildings renovated within three years. At that time, 55 schools and 967 new classrooms were built in Budapest. The schools also included official housing. In addition, they also took care of the heating systems of the buildings, the classrooms' furniture and the designing of the schoolyards and roof terraces. In 1913 the curriculum for the Budapest schools was published and workshops were established for the production of teaching materials. As a result of these actions, the equipment of public schools in the capital improved considerably (Németh 2006, pp. 81).

In the development of reform pedagogy and experimental pedagogy, as well as child research in Hungary, primary school teachers and teachers from teacher training institutions played an important role. In the professional knowledge of modern primary school teachers, reform pedagogical semantics also played an important role in this epoch. From the criticism of Herbartianism and after the

${ }^{3}$ Ödön Palasovszky (1899-1980): hungarian poet, representative of the hungarian avant-garde theatricals.

${ }^{4}$ Olga Szentpál (1895-1968): hungarian musician, dance pedagogue. 
passage through experimental pedagogy, the pedagogical knowledge of elementary school teachers in the life reform and reform pedagogical thought finally found its modern and legitimate form. This semantics brought new magic words. The child's own right became the new regulative principle and the basis of the professional ethos. The pedagogical reference as a social place can help this right of one's own to become reality (cf. Tenorth, 1992, pp. 369-370).

At that time, this professional group also meant an ever-stronger professional competence in Hungary. Their outstanding task was above all reflected in the reception of the modern psychological-pedagogical movement, which experienced its heyday after the turn of the century. Furthermore, the results of pedology were disseminated in Hungary. László Nagy (1857-1931), a teacher at the Budapest State Teacher Training Institute, and his colleagues founded the Hungarian Society for Child Research in 1906. They became the organizers of the Society, who expected from the dissemination of modern pedagogical-psychological endeavors - similar to the foreign representatives of the direction (Depaepe, 1993) - the establishment of educational science on an experimental, empirical basis, respectively the dissemination of the new pedagogical viewpoint. In order to disseminate the childcentred pedagogical view, training courses were held for practicing teachers and books and magazines were published: from 1907 the independent journal of the Society «A gyermek» (The Child) was published under the editorship of László Nagy. Outside the capital, new centres for children's studies were also established. As one of the most outstanding personalities of theoretical pedagogy in Hungary, Ödön Weszely did much to spread the movement and to make the results of child studies and reform pedagogy accessible to other teachers (Köte, 1987; Németh, 1990, 2006, pp. 82-87).

Based on László Nagy's theory of the development of the child (Nagy, 1912), the «New School» of the Pedological Society in Hungary was founded in 1914 under the leadership of Mrs. Domokos Lászlóné for 6-14 year old boys and girls. The school wanted to provide basic education in the first four classes and lower secondary school in the next four years. For those who wanted to continue their studies in a commercial or art school, it ensured a completed education. The reform school existed in Budapest until 1949, when it was closed by the communist regime.

The new pedagogical ideas and the processes behind them, the development trends of the various educational systems and the teaching profession in Central Europe, the peculiar traits in the Hungarian reception of the various scientific trends - they are present «like the sea in a drop» in the first Hungarian pedagogical encyclopedia of the century, the Encyclopedia of National Education, which appeared between 1911 and 1915. The professional edition was published for Hungarian teachers, whose number increased to more than 40 thousand after the turn of the century. Teachers were strong in their total number and outstanding in their professional quality. The encyclopedia summarizes all knowledge in the field of pedagogy and school administration necessary for a modern Hungarian primary school teacher (Németh, 1999). The pedagogical encyclopedia examines in detail the different currents of experimental psychology and pedagogy, children's studies and psychology, presents the work of the most important foreign and Hungarian representatives. It gives an overview of the various reform schools of that time, 
especially the English «New School» movement and the resulting national pedagogical reform trends and new methodological ideas (Abbotsholme, Ecole des Roches, Landerziehungsheim, Reformschule, Parker-Schule, Arbeitsschule, Waldschule, Pfadfinder). Tolstoy, Ellen Key, Ruskin, Berthold Otto appear as independent keywords, Dewey is also mentioned in the term concentration, whose work School and Society was published in Hungarian in 1912 (Németh, 2002).

The first place of cooperation was the magazine Népmúvelés (National Education), the press organ of the educational reform, which was founded in 1906 with the support of the mayor. It was published until 1918 (after 1912 with the title New Life - Új Élet). It serves not only as a forum for educators in the capital, but also as a press organ of cultural policy and education of the Bárczy programme. The magazine «Népmüvelés» provided opportunities for publication not only for representatives of Hungarian pedology and experimental psychology, but also - in addition to the magazines Twentieth Century and The West - for the various directions of the Hungarian life reform movement, from anarchist, syndicalist and Tolstoyan aspirations (Ervin Szabó ${ }^{5}$, Jenő Schmidt ${ }^{6}$, Ervin Batthyányi ${ }^{7}$ ) to numerous approaches of the Hungarian secession. In the first period of the magazine, the leading figures of the artistic community in Gödöllö also played an important role. Among the authors of the magazine Népmüvelés, among the lecturers and the audience of the courses and scientific lectures of the Pedagogical Seminary, as well as among the members of the Society for Children's Research in the 1910s were the representatives of the different directions of the Hungarian Secession, the Hungarian movement art and the new musical and artistic education as well as the Sunday circle (Németh, 2006, pp. 85).

The representatives of these initiatives had the opportunity to express their opinions on the pages of the magazine about the new urban culture, about the new directions of urban modernization, about the relationship between art and education, about the new tasks of popular education and school, about the new man and the new society, about the changed relationship between man and woman, about the new moral and the new education, about the art of the child, about the importance of the return to folk art as the natural way of life, about the «third way» to the renewal of Hungarian culture and society (Németh, 2004).

The other spiritual centre for the cooperation of the various life reform efforts and reform pedagogy in the service of educational and school reform in Budapest, which lasted until the end of the war, was the Pedagogical Seminar, which was established in 1912 under the direction of Ödön Weszely (1867-1935) (Németh, 1990, pp. 13-14; Mann, Hunyady \& Lakatos, 1997) for the further education of teachers in the capital.

5 Ervin Szabó (1877-1918): hungarian social scientist, library director, anarcho-syndicalist revolutionist.

6 Jenő Henrik Schmitt (1851-1916): hungarian gnostic philosopher, anarchist.

7 Ervin Batthyányi (1877-1945): hungarian landowner, publicist, school founder. 


\section{Reform Pedagogy in the Time of the Horthy Era}

With the end of the revolutions (Hungarian Civil Democratic Revolution in 1918 and the proletarian dictatorship in 1919), the first, exciting phase of the relationship between Hungarian life reform and reform pedagogy comes to an end. This phase, which was also not free of extremism, was characterized by the vibrant symbiosis of the two movements. These new initiatives of reform pedagogy already spread in the new epoch of Hungary's economic, social and political development in the so-called Horthy Era, which began with the period of 1920, which was decisively determined primarily by the consequences of the peace agreement of a lost war. The Treaty of Trianon (1920) shook all layers of Hungarian society.

Therefore, the development of education in the era of the Bethlen consolidation, which began in 1921, became a strategically important task. The background to this cultural policy was the idea of the so-called "cultural superiority", the ideology which came from a prominent cultural politician, the then conservative Minister of Culture Kuno Klebelsberg (1875-1932). In his opinion, neonationalism, a Christiannational ideology with a redesigned content, was an important means to this end. With its help the formation of a highly qualified (but with national and revisionist thoughts filled) «intelligence elite» was realized, and beside it the general raising of the cultural level of the population was urged.

It was in this interest that Klebelsberg had the country's unified institutional system organized during this period, the academy received support from the state, the museums and archives were united in a unified organization, the university foundations, which begun in the 1910s (Debrecen, Szeged, Pécs), were continued, their institutes were expanded, and between 1924 and 1926 he finally began the modernization of the secondary schools, alongside which a large number of elementary schools were built (Ladányi, 1999, p. 51).

In parallel with these efforts, the reform of teacher education took place in the 1920s: the status of the 5-year teacher training centre was strengthened, citizen schools were recognised as secondary schools after 1927; the Teacher Training College from Budapest was moved to Szeged and given the name: College for Civic Teacher Training. According to the law of 1924, teacher training institutes were established at all Hungarian universities in addition to the philological faculties, to enable future high school teachers to acquire all their specialist knowledge in addition to their university studies within an organised curriculum. Accordingly, only a student who was enrolled in the philological faculty of a university, who had chosen at least two secondary school subjects, and who had successfully completed the prescribed lectures and seminars at the university and the teacher training institute could obtain a qualification as a teacher.

From the 1920s onwards, the enthusiasm of the earlier movements that were decisive for social and human change was replaced by the synthesizing, preserving, the unaltered, the Absolute-seeking aspirations. The social themes now remain more on the national level. More and more the research of national peculiarities and the Hungarian soul appeared as objects of investigation. The social theme, which was again formulated in a broad context in the 1930s, now appeared less on the theoretical than on the practical level, in sociography, in village research and in the 
popular movement. The new rhetorical means, which were dominant in the tenor of the Hungarian life reform movement, were at that time fundamentally influenced by the utopia after the third way of László Németh ${ }^{8}$ («Garden-Hungary», «family», «Falanster», «the new nobility of the spiritual elite», «quality socialism») and by the national radicalism of Dezső Szabó (new Hungarian land seizure). It was at this time that Zoltán Kodály's music pedagogy, rooted in folk music, developed, and János Karácsony ${ }^{9}$ acknowledged in his works that there was a special Hungarian way of thinking (the wonderful one), and thus a special Hungarian world view. In his works, the life reform movements, which are related to the rhetoric of the popular movement, and the various reform pedagogical and psychological conceptions are mixed in a special way with the ideas that support the rebirth of Protestantism (Németh 2006, p. 88).

One of the most famous Hungarian reform schools was founded in 1915 by Mrs. Nemes Müller Márta. This school worked until 1943. The theoretical conception and practice are connected with the international efforts of reform pedagogy in the 1920s. The founder of the school lived in Belgium for a long time at the beginning of the century, where she became acquainted with the most important early reform pedagogical efforts. The pedagogy of the important Belgian reform pedagogue Ovide Decroly had a great impact on her conception. Her experiences in Belgium led her to mature the decision to find such schools, where the focus was on «work for society, where moral theses and feelings can be put into practice». Based on these basic principles, she developed the theoretical basis and the curriculum of her school between 1907 and 1912 and then opened her first school for 6-14 year olds in Brussels in 1912. This free school experiment lasted until the outbreak of World War I, and when she had to return home, she founded a new private school in Budapest in 1915, the «Családi Iskola» (Family School) (Németh \& Pukánszky. 1999, p. 252).

Montessori's pedagogical ideas quickly attracted the attention of Hungarian pedagogues. The first Montessori Kindergarten was founded in 1912 in the convent of the Missionary Sisters of Mary of the Franciscan Order. Some Italian members of the order were trained by Montessori in Rome and received a diploma. One of the sisters then taught the Hungarian sisters the Montessori method. The most famous personality of the Hungarian Montessori pedagogy was Erzsébet Burchardt-Bélavári (1897-1987), who between 1924 and 1944 also directed kindergartens and from 1928 to 1941 a school according to the method of the Italian pedagogue. When she became acquainted with Montessori's work, she went to Holland, where in 192324 she acquired the right to teach in a Montessori children's home during a course in Amsterdam. Afterwards she worked for a short time in Vienna in a Montessori kindergarten; when she returned to Budapest she opened a kindergarten and then a school. From 1930 onwards she gave further education courses, practice-oriented lectures for kindergarten teachers, teachers and parents at her institution and at the Budapest Educational Institution for Kindergarten Teachers (Burchard, 1987, p. 1187).

\footnotetext{
${ }^{8}$ László Németh (1901-1975): hungarian doctor, essayist, writer, pedagogue.

9 Sándor Karácsony (1891-1952): hungarian pedagogue, theoretician.
} 
Among Rudolf Steiner's Hungarian followers one can mention Dr. Mária Göllner (1894-1982), who as Steiner's personal pupil got to know Antroposophy and became a member of the Goetheanum in Dornach in 1924. She founded the first anthroposophical group in Hungary in 1926 and in September of that year she also opened her bilingual (German-Hungarian) Waldorf School, which operated in a garden district of Budapest (Kis-Svábhegy) until 1933 (Vekerdy, 1990; Vámos-Nagy, 1989).

\subsection{The Emancipation of Reform Pedagogy}

In the 1920s, pedagogy also developed into a university discipline to a considerable extent in Hungary with a strong German reception, and educational science took a big step forward on the way to becoming a modern scientific discipline (Stiehweh, 1994; Tenorth-Horn, 2001; Horn, 2003; Németh, 2002, pp. 372-374). The elements of reform pedagogy and experimental pedagogy that were regarded as despised elementary school pedagogy or pedagogical utopia in the pre-war period are increasingly linked to this process of institutionalisation. First and foremost, the long-term ideas that were related to the ideology of the educational reform unfolding during this period came to the fore. The extent of their development depended on the one hand on the orientation of the various university professors, and on the other hand on the special tasks of the individual universities. The practice-oriented approach to school education was characteristic of all universities. In this broad reform movement, in the internal school reform, the permanent didactic-methodical elements of reform pedagogy already played an important role.

A phenomenon of its own is that during the first decades the centre of the developing new endeavours in the capital city was the institutionalisation of reform pedagogy at the universities in the countryside. A typical example of the changed prestige of reform pedagogy is the reception by Maria Montessori, who visited Hungary several times in the 1930s at the invitation of the Hungarian Pedagogical Society. She was received by the figures of pedagogical and public life as an internationally famous personality of education, her program was also reported in the Hungarian press. Gyula Kornis, President of the Hungarian Pedagogical Society, gave a speech at the Hungarian Academy of Sciences in her honour. Then the Minister of Culture, Kuno Klebelsberg, gave a solemn lunch to the honour of the «dottoressa» in the National Casino, to which the «mandarins» of Hungarian science were invited (Rajnai, 2002).

In the institutionalisation of reform pedagogy at universities, three typical models can be distinguished in Hungary (Németh, 2006a):

The first direction, the development of university pedagogy in the spirit of experimental pedagogy after the turn of the century, was most consistent at the University of Pécs. The institute, founded in 1923 by Ödön Weszely (1873-1935), professor of pedagogy, also included a specialist library with 2000 volumes, a pedagogical research laboratory and a museum. An important chapter in Weszely's early pedagogical work was the activity between 1906 and 1918 in the educational reform of Budapest. He was the first director of the Pedagogical 
Seminar and the editor of the cultural and educational press organ of the Bárczy programme, the magazine «People's Education». In Weszely's life's work the late Herbartianism is completed, especially the most complete reception of W. Rein's conception. Thanks to this, the influence of the new pedagogical concepts from the time after the turn of the century, pedology and the new research results of modern psychology become noticeable in his theoretical and school pedagogical works. The orientation of his systematizing works from the twenties in the humanities and cultural pedagogy represents a peculiar bridge, a transition between late Herbartianism and the cultural pedagogy of the thirties (Németh, 1990).

The second direction characterized the reception of reform pedagogy in the spirit of the Rousseau Institute in Geneva at the University of Budapest. The most significant achievement of the twenties, apart from the increasing dissemination of the humanities, was that the teaching of pedagogy at universities led to an increase in the importance of the concept of reform pedagogy based on modern child psychology. Gyula Kornis ${ }^{10}$, the then professor of philosophy himself, regularly offered lectures in child psychology. Parallel to these lectures, Cecil Bognár (1883-1967), later professor of pedagogy at the University of Pécs and Szeged, was appointed private lecturer in child psychology (pedology) in 1923. Elemér Kenyeres (1891-1933), one of the most important representatives of reform pedagogy in Hungary, followed him in 1930. In addition to Weszely, he represented in the academic field the point of view of the school practice-oriented «elementary school teacher». From 1926 he studied with a scholarship at the University of Geneva. His acquaintance with the important representatives of the Rousseau Institute in Geneva played an important role in his later academic career. At the end of the 1920s, Piaget's reception in Hungary also began in response to the influence of Kenyeres (Németh, 1993).

The third direction, the reception of the French psychological directions and the reform pedagogy in the service of the reform of teacher training, came into being at the University of Szeged. In its background was the restructuring of the Hungarian teacher training for secondary schools (in Hungary so-called «citizen school») ${ }^{11}$. The institution, which was formerly active in Budapest, was implemented as a university next to the university in Szeged. At the same time, the University of Szeged established the first chair of educational psychology in Hungary, whose professor Hildebrandt Várkonyi (1888-1952) shortly before that extended his philosophical and psychological studies as a scholarship holder at the Sorbonne in Paris. In his lectures and in his scientific journalism he received the most modern psychological currents of the epoch (Piaget, Janet, Freud, Jung, Adler) and the efforts of reform pedagogy. His research was characterized by a strong orientation towards pedagogical psychology. Numerous talented students worked for him at the institute he headed and in his research laboratory. With his support, one of his

10 Gyula Kornis (1885-1958): hungarian catholic priest, piarist monk, philosopher, university professor, cultural politician.

${ }^{11}$ Schools at a lower secondary level - different from lower gymnasiums. 
students, Erzsébet Dolch (1906-2002), ran the «Garden School» (Kerti Iskola), one of the reform schools in Szeged. Another student of Várkonyi, Erzsébet Baranyai, the first private lecturer of pedagogy in Hungary, also became a recognized expert of pedagogical psychology and reform pedagogy (Pukánszky, 2002).

The practicing school of the Pedagogical University in Szeged, which is linked to the University, also played an important role in the dissemination of reform pedagogical efforts in school practice. The students, who did their school internship in this school, not only learned about the general theoretical objectives of reform pedagogy, but they could also directly experience the practical work in its spirit. After the university students came from all over the country, the effect of new pedagogical ideas spread all over Hungary.

\section{Conclusion}

The dynamics of the development of the processes presented in our work remain intact even in the short democratic transition phase (1945-1949) after the Second World War. The particular pedagogical aspirations of the earlier times lived on, respectively awakened; the traditional Christian directions, the spiritual science pedagogy, which played a dominant role in university pedagogy, the education of the nation, the pedagogical aspirations of folk writers and the popular movement, the various directions of reform pedagogy. In the years after the Second World War, the approach of reform pedagogy and child research, the pedagogical way of thinking that focuses on the peculiarities of the child's age and the self-activity of the child, came more and more to the fore.

After the nationalization of schools (1948), the communist teaching model and the communist educational science were put into practice with the increasingly coarse means of open state and political violence. As a result, the unified state school, the unified communist education and youth movement, which put the whole Hungarian school system and the entirety of education and training at the service of the construction of socialism-communism, was established in Hungary as well. Thus the dictatorial school of a dictatorial state was realized, in which the foundations of the external and internal unity were the socialist-communist ideology, the socialistcommunist target and educational apparatus, the teaching material filled with Marxism and Leninism, and the obligatory materialism-theism. In the Hungarian society, which became more and more monolithic due to the effect of the state dictatorship, the professional autonomy, the critical spirit, the professionalism, which observes the phenomena of the world in their objectivity, is disappearing more and more (Németh \& Garai, 2019, pp.226-229).

\section{References}

Baader, M. S. (2005). Erziehung als Erlösung. Transformationen des Religiösen in der Reformpädagogik 1880-1950. Weinheim: München.

Bergson, H. (1896): Matière et mémoire. Paris: Libraire Félix Alcan. 
Bilstein, J. (2000). Das Jahrhundert des Kindes in Worpsede. In Baader M. S. et. al. (Ed.), Ellen Keys reformpädagogische Vision (pp.161-190). Basel.

Borus, R. (Ed.), (1978). A nagy század tanúi. [Witnesses of the Great Century] Budapest: RTV Minerva.

Burchard, E. (1987). Visszaemlékezésem Montessori rendszerű magánóvodámra és «magán» népiskolámra. [My reminiscence of my Montessori private nursery and «private» public school] Pedagógiai Szemle [Pedagogical Review], 12(2), 1187-1207.

Depaepe, M. (1993). Zum Wohl des Kindes? Pädologie, pädagogische Psychologie und experimentelle Pädagogik in Europa und in den USA, 1890-1940. Weinheim: Deutscher Studien Verlag.

Fenyves, M. (2016). Valéria Dienes (1879-1978). In Fenyves, M., \& Dienes, G. (Eds.), The reform of dance in the attraction of the art of movement. Movement science, philosophy, psychology, pedagogy, art theory. Dance theory collection. Budapest: Orkesztika Alapítvány.

Földiné, Irtl M., \& Komár, L. (2017). Indo-Tibetan Influences and Life Reform in Hungary in the Interwar Period. In. Németh, A.,Stöckl, C., \& Vincze B. (Eds.), Survival of Utopias - Life Reform and Progressive Education Austria and Hungary (pp.115-132). Wien: Peter lang Publisher.

Gellér K., \& Keserü K. (1994). A gödöllöi müvésztelep. [The Artist Community of Gödöllő]. Budapest: Cégér.

Gergely, A. (Ed.) (2003). Magyarország története a 19. században. [The History of Hungary in the 19th Century]. Budapest: Osiris.

Horn, K.-P. (2003). Erziehungswissenschaft in Deutschland im 20. Jahrhundert. Bad Heilbrunn: Klinkhardt.

Kékesi, Z., \& Schuller, G. (2003). 1926. Művészetközöttiség és jelszerűség. Megjelenik a Tisztaság könyve és a Dokumentum. [1926. Between art and symbolism. The Book of purity and the Document are published] Literatura, 29(4), 427-440.

Köte, S. (1983). Egy útmutató pedagógus. [A leader pedagogue]. Budapest: Tankönyvkiadó

Krabbe, W. (2001). Die Lebesreformbewegung. In Buchholz Kai et al. (Ed.), Die Lebensreform. Entwürfe zur Neugestaltung von Leben. Band 1 (pp. 25-30). Darmstadt: Häusser Verlag.

Ladányi, A. (1999). Magyar felsőoktatás a 20. században. [Hungarian higher education in the 20th century]. Budapest: Nemzeti Tankönyvkiadó. 
Mann M., Hunyady Z., \& Lakatos Z. (1997). A Fövárosi Pedagógiai Szeminárium története. [History of the Pedagogical Seminar of Budapest]. Budapest: FPI.

Mietzner, U. (2002). Lebensreformerische Konzepte von Kindheit, Erziehung und Familie in der Kunst um 1900. Jahrbuch für Historische Bildungsforschung. 8. 81-106.

Nagy, A., \& Németh, A. (2017). How Austro-German Life Reform were received based on the Examples of the Szentendre Bubaán Colony and Életreform Magazine. In Németh, A. ,Stöckl, C., \& Vincze B. (Eds.), Survival of Utopias Lifer Reform and Progressive Education Austria and Hungary (pp. 55-70). Wien: Peter Lang Publisher.

Nagy, L. (1908). A gyermek érdeklődésének lélektana. [The psychology of the child's interest]. Budapest. German version:

Nagy, L. (1912): Psychologie des Kindlichen Interesses. Leipzig.

Németh. A. (1987). Weszely Ödön és a Népművelés. [Ödön Weszely and the Folk Education]. Budapesti Nevelö, 11, 21-28.

Németh A. (1990). Weszely Ödön [Ödön Weszely]. Budapest: OPKM.

Németh A (1993). Kenyeres Elemér élete és munkássága [The life and work of Elemér Kenyeres]. In Balogh, L. (Ed.), Neveléstörténeti Füzetek 12. [Booklets of Education History] (pp. 63-69). Budapest: OPKM.

Németh A. (2002). A magyar neveléstudomány fejlödéstörténete [The History of Hungarian Education Development]. Budapest: Osiris.

Németh A. (2004). Fejezetek a magyar egyetemi neveléstudomány és a reformpedagógia ambivalens kapcsolatából. [Chapters on the ambivalent relationship between Hungarian university education and reform pedagogy] In Németh, A. (Ed.), A szellemtudományi pedagógia magyar recepciója [The reception of pedagogy as a spiritual science in Hungary]. Budapest: Gondolat Kiadó.

Németh A. (2006). Die Lebensreform und ihre pädagogischen Rezeption in Ungarn: Lebensreform und Bildungsreform. In Skiera, E., Németh A., \& Mikonya Gy. (Eds), Reformpädagogik und Lebensreform in Mitteleuropa - Ursprünge, Ausprägung und Richtungen (pp. 58-88). Budapest: Gondolat Kiadó.

Németh, A. (2006a): A chapter in the history of an ambivalent relationship: Connections between the «new education movement» outside of the universities and academic pedagogy in Hungary. In: Hofstetter, R., \& Schneuwly, B. (Eds.): Passion, Fusion, Tension: New Education and Educational Sciences. (pp. 169190). Bern: Peter Lang Verlag

Németh, A. (2017). Életreform törekvések az Osztrák-Magyar Monarchiában és hatásuk a korabeli művészeti, művelődési és pedagógiai reformokra. In 
Sármány-Parsons, I., \& Szegő, Gy. (Eds.), Az Osztrák-Magyar Monarchia mint művészeti színtér (pp. 54-93). Budapest: Műcsarnok.

Németh, A. (2020). Life Reform in Hungary and the Arts: International Reception and National Characteristics. In Vincze, B., Kempf, K., \& Németh, A. (Eds.), Hidden Stories - the Life Reform Movements and Art (pp. 29-50). Berlin et. al.: Peter Lang International Academic Publishers. doi: 10.3726/b16794

Németh. A. (1987). Weszely Ödön és a Népművelés. [Ödön Weszely and the Folk Education]. Budapesti Nevelö, 11, 21-28.

Németh, A., \& Garai, I. (2019). Disciplinary Changes in the Hungarian Pädagogik from the second half of the 19th century to the collapse of Stalinist-type dictatorship. In Kudláčová, B., \& Rajský, A. (Eds.), Education and "Pädagogik"Philosophical and Historical Reflections : Central, Southern and South-Eastern Europe (pp. 2010-229.). Berlin: Peter Lang.

Németh, A., \& Pukánszky, B. (1999). Magyar reformpedagógiai törekvések a XX. század első felében. [Hungarian reform pedagogy efforts in the first half of the 20th century] Magyar Pedagógia [Hungaryan Pedagogy], 99, 245-262.

Németh, A., \& Pukánszky, B. (2019): Life reform efforts in the Austro-Hungarian monarchy and their impact on Hungarian cultural and pedagogical reforms. Paedagogica Historica, 1-18. doi: 10.1080/00309230.2019.1586736

Oelkers, J. (1989). Reformpädagogik - eine kritische Dogmengeschichte. Weinheim, München.

Peters, U. (2005). Esoterik. Köln: DuMont.

Pukánszky, B. (2002). Reformpedagógia Szegeden a két világháború között. [Reform pedagogy in Szeged between the two world wars]. In Németh, A. (Ed.), Reformpedagógia-történeti tanulmányok [Studies on the history of reform pedagogy] (pp. 101-120). Budapest: Osiris.

Rajnai J. (2002). A Montessori pedagógia fogadtatása a harmincas évek hazai pedagógiai sajtójában [The reception of the Montessori pedagogy in the Hungarian pedagogical press of the thirties]. In Németh, A. (Ed.), Reformpedagógia-történeti tanulmányok. [Studies on the history of reform pedagogy] (pp. 121-136). Budapest: Osiris.

Ritoók E. (1993). A szellem kalandorai [Spiritual adventurers]. Budapest: Pesti Szalon.

Scholz, J. J. (2002). «Haben wir die Jugend, so haben wir die Zukunft». Die Obstbausiedlung Eden/Oranienburg als alternatives Gesellschafts- und Erziehungswerk. Berlin.

Skiera E. (2006). Über den Zusammenhang der Lebensreform und Reformpädagogik. In Skiera, E., Németh A., \& Mikonya Gy. (Eds.), Reformpadagogik und 
Lebensreform in Mitteleuropa - Ursprünge, Ausprägung und Richtungen (pp. 22-47). Budapest: Gondolat Kiadó.

Skiera, E. (2003). Reformpädagogik in Geschichte und Gegenwart. Eine kritische Einführung. München und Wien.

Skiera, E. (2017). Lebensreform und Reformpädagogik. In Idel, T. S., \& Ulrich, H. (Eds.), Handbuch Reformpädagogik (pp. 46-59). Weinheim, Basel: Beltz.

Stichweh, R. (1994). Wissenschaft, Universität, Professionen. Frankfurt am Main: Suhrkamp.

Szabadi J. (1978). Lesznai Anna, a festő és az iparművész [Anna Lesznai, painter and industrial artist]. In Gergyely, T. (Ed.), Lesznai Képeskönyv. [Lesznai Picture Book]. Budapest: Corvina.

Tarjányi E. (2002). A szellem örvényében [In the swirl of the spirit]. Budapest: Universitas.

Tenorth, H.-E., \& Horn, K.-P. (2001). Erziehungswissenschaft in Deutschland in der ersten Hälfte des 20. Jahrhunderts. In Horn, K.-P., Németh, A., Pukánszky, B., \& Tenorth, H.-E. (Eds.), Erziehungswissenschaft in Mitteleuropa. Aufklärerische Traditionen - deutscher Einfluß - nationale Eigenständigkeit (pp. 176-191). Budapest: Osiris.

Tenorth, H.-E. (1992). Verbesserung des Argumentierens in der Pädagogik durch Argumentationsanalysen. In Paschen, H., \& Wigger, L. (Eds.), Pädagogisches Argumentieren (pp. 357-375). Weinheim: Deutscher Studien Verlag.

Vámosi Nagy, I. (1993): A kissvábhegyi Waldorf-iskola [The Waldorf School of Kissvábhegy] 1926-1933. I. Országépítő, 2.

Wolbert, K. (2001). Die Lebensreform. Anträge zur Debatte. In Buchholz Kai et al. (Eds.), Die Lebensreform. Entwürfe zur Neugestaltung von Leben. Band 1 (pp. 13-24). Darmstadt: Häusser Verlag.

Zaletnyik. Z., \& Repiszky, T. (Eds.) (2012). A gyógyító mozgás művésze - Madzsar Alice emlékének [The art of healing movement - for the memory of Alice Madzsar]. Budapest: Semmelweis Publishing House and Multimedia Studio. 